\title{
max \\ Effects of Residual Xanthate on Flotation Efficiency of a Cu-Zn Sulfide Ore
}

\author{
Yasemin Ozturk *, Ozlem Bicak and Zafir Ekmekci
}

check for updates

Citation: Ozturk, Y.; Bicak, O.; Ekmekci, Z. Effects of Residual Xanthate on Flotation Efficiency of a Cu-Zn Sulfide Ore. Minerals 2022, 12, 279. https://doi.org/10.3390/ $\min 12030279$

Academic Editors: Hongbo Zhao, Jiushuai Deng and Abhilash

Received: 25 January 2022

Accepted: 22 February 2022

Published: 23 February 2022

Publisher's Note: MDPI stays neutral with regard to jurisdictional claims in published maps and institutional affiliations.

Copyright: () 2022 by the authors Licensee MDPI, Basel, Switzerland. This article is an open access article distributed under the terms and conditions of the Creative Commons Attribution (CC BY) license (https:// creativecommons.org/licenses/by/ $4.0 /)$.

\author{
Mining Engineering Department, Hacettepe University, Beytepe, Ankara 06800, Turkey; \\ obicak@hacettepe.edu.tr (O.B.); zafir@hacettepe.edu.tr (Z.E.) \\ * Correspondence: yozdil@hacettepe.edu.tr
}

\begin{abstract}
Reuse of process water in the flotation of sulfide ores has crucial importance for environmental sustainability and improved process economy. However, the chemistry of process water may be a critical subject for the flotation efficiency as the dissolved ion concentration increases with water reuse. In this study, the effects of water reuse on the flotation efficiency of a Cu-Zn sulfide ore were investigated. The flotation flowsheet consists of a pre-flotation section to remove the naturally floatable talc particles, and sequential copper and zinc flotation sections. Calcium, sulfate, thiosulfate, and xanthate were found as major contaminating ionic species in the process water discharged from flotation circuits. The flotation tests with recirculated water from the zinc rougher tailing revealed that the presence of residual xanthate caused unintentional activation of copper minerals in the pre-float section. Copper recovery increased in the pre-flotation section and resulted in the loss of copper to the pre-float concentrate, which is considered as a tailing stream in the current flowsheet. Various types of activated carbon samples were tested to remove the residual xanthate from the tailing water. The carbon samples could be regenerated by heat treatment and reused for water treatment. Performance of the activated carbon samples was directly related to the pore size and surface area. Carbon-treated tailing water could be re-used in flotation without affecting the flotation performance.
\end{abstract}

Keywords: water reuse; water treatment; residual xanthate; flotation efficiency; sulfide minerals

\section{Introduction}

In mineral processing plants, depending on the method of concentration, there is so much need for water as a medium and for transferring the pulps in the circuit from one point to another. It is well known that the flotation is the most affected process from water chemistry among the other mineral processing methods.

Water quality for flotation on a mine site can change substantially over time [1-3]. The composition of flotation water depends on the ore being processed, the reagents, the water source, and the way the site water system is managed. Variation in water quality is undesirable because it could complicate operating conditions and compromise flotation performance [4-8]. Hence, the quality of water should be maintained at a distinct level and the fluctuations should be prevented. In this case, usually freshwater is fed to the concentration plants to maintain a certain level of pollution. However, this increases freshwater consumption and may cause process water discharge without any treatment. A number of research works have focused on the reuse of tailing water in flotation circuits to minimize freshwater consumption [8,9]. On the other hand, the chemistry of the system may change by water recirculation due to the accumulation of various inorganic and organic species that affect process efficiency in different ways.

Xanthates are commonly used as collectors in the flotation of sulfide minerals. Although most of xanthate is found to be consumed during flotation, there are still residual xanthate molecules in the flotation tailings [10]. The amount of residual xanthate in process water depends on the $\mathrm{pH}$, temperature, seasonal variations, and the site water management 
plan [11]. Residual xanthate and its by-products in the recirculated water may cause the loss of selectivity between minerals and affect flotation efficiency adversely [8]. Furthermore, disposal of residual xanthates and their oxidation products may have environmental consequences due to the possible contamination of soil and groundwater sources [12]. As deleterious effects on flotation plant efficiency have been considered, removal of residual xanthate is highly desirable.

In recent years, several methods have been developed to remove the residual xanthate from the aqueous solutions, such as chemical oxidation by ozone $[13,14]$, hydrogen peroxide, Fenton and simulated solar photo-Fenton processes [15]; biodegradation [16], adsorption by bentonite [17,18], modified montmorillonites [19] and activated carbon [20]. Chemical oxidation is an efficient method, however considering the generation of the by-products that may be harmful to the process, it is not efficient in practice. Biodegradation is an economic but slow process, so treatment of a large volume of flotation tailings would be a challenge. Adsorption is easy to apply method and may be advantageous due to the none of by-product production. Activated carbon adsorption is highly effective for the treatment of organics in mining effluents, however it requires regeneration to make the process economical [8].

In this research, the influence of water reuse on the flotation performance of a $\mathrm{Cu}-\mathrm{Zn}$ sulfide ore from Turkey has been studied. The ore contains naturally floatable talc minerals which could be detrimental in the copper flotation stage. Talc particles report directly to the copper concentrate and decrease the grade of the concentrate. This problem could be solved by using organic reagents (CMC, guar gum, etc.) to depress the talc particles [21,22]. However, the test work results with this particular ore showed that not only the talc but also the copper minerals were depressed to some extent, which caused significant losses in copper recovery. Hence, pre-flotation of talc particles before the copper flotation stage was found to be the most effective method [23].

In the first phase of the research, batch scale flotation tests were conducted to demonstrate the effect of water recirculation on process water chemistry and flotation efficiency. Grade and recovery values of $\mathrm{Cu}$ and $\mathrm{Zn}$ were measured to show the effect of water constituents on flotation. In the second phase, it was aimed to eliminate the detrimental effects of xanthate on flotation. The activated carbon adsorption method was applied to remove the residual xanthate from process water. Flotation tests were also performed with treated water to observe the impact of water treatment on flotation performance.

\section{Materials and Methods}

\subsection{Materials}

Four granular activated carbon samples (AC-1, AC-2, AC-3, AC-4) with different surface characteristics were used to remove xanthate in flotation process water. AC-1, AC-2, and AC-3 were supplied by an industrial plant, and AC-4 was obtained from a commercial supplier. The specific surface area and pore structure characteristics were determined by nitrogen adsorption using the surface area analyzer (Autosorb-6, Quantachrome Corporation, Boynton Beach, FL, USA) at METU Central Laboratory, Ankara. The sample was degassed under vacuum at $300{ }^{\circ} \mathrm{C}$ for three hours before the measurement. The surface area of activated carbon was estimated by the Brunauer-Emmett-Teller (BET) method. Micropore size distribution was determined by the Horvath-Kawazoe method. Surface properties are summarized in Table 1.

Sodium isopropyl xanthate (SIPX, supplied by an industrial plant) was used to prepare xanthate solutions. A Cu-Zn sulfide ore was used for flotation tests. The head grade of the ore is $0.83 \% \mathrm{Cu}, 25.16 \% \mathrm{Fe}, 0.22 \% \mathrm{~Pb}, 2.23 \% \mathrm{Zn}, 0.95 \mathrm{~g} / \mathrm{t} \mathrm{Au}$ and $31.9 \mathrm{~g} / \mathrm{t} \mathrm{Ag}$. The master composite sample consists mainly of pyrite $(\sim 60 \%)$, silicates (quartz, feldspars, chlorite, micas and talc), carbonates and significant Fe-oxides $(\sim 5 \%)$. The major copper mineral is chalcopyrite (1.6\%), traces of bornite, covellite/chalcocite and enargite, sphalerite $(2.7 \%)$, galena $(0.3 \%)$, and other sulfides are also present [23]. 
Table 1. Surface area, pore volume, and pore size of activated carbon sample.

\begin{tabular}{cccc}
\hline & Surface Area & Pore Volume & Pore Size \\
\hline & $\mathrm{m}^{2} / \mathrm{g}$ & $\mathrm{cc} / \mathrm{g}$ & $\AA$ \\
\hline $\mathrm{AC}-1$ & 1192 & 0.49 & 5.83 \\
\hline $\mathrm{AC}-2$ & 1019 & 0.40 & 5.38 \\
\hline $\mathrm{AC}-3$ & 906 & 0.36 & 5.36 \\
\hline AC-4 & 1699 & 0.68 & 5.43 \\
\hline
\end{tabular}

\subsection{Adsorption Tests}

Effect of initial concentration of xanthate and contact time was tested by mixing $0.5 \mathrm{~g}$ activated carbon with $100 \mathrm{~mL}$ of $50 \mathrm{mg} / \mathrm{L}, 100 \mathrm{mg} / \mathrm{L}, 200 \mathrm{mg} / \mathrm{L}, 400 \mathrm{mg} / \mathrm{L}$, and $800 \mathrm{mg} / \mathrm{L}$ xanthate for different time intervals during $210 \mathrm{~min}$. Xanthate was measured by UV-Vis Spectrophotometry (Multispect 1501, Shimadzu, Kyoto, Japan). The highest intensity peak at $301 \mathrm{~nm}$ was used to determine the concentration of xanthate in water samples. The uptake of the activated carbon, $Q_{e}(\mathrm{mg} / \mathrm{g})$, at equilibrium was calculated by the following equation:

$$
Q_{e}=V \frac{C_{0}-C_{e}}{m}
$$

where $C_{0}$ is the initial and $C_{e}$ is the concentration of the xanthate $(\mathrm{mg} / \mathrm{L})$ in solution at equilibrium; $V$ is the volume of the solution $(\mathrm{L})$ and $m$ is the weight of the activated carbon $(\mathrm{g})$.

\subsection{Flotation Tests}

The flotation conditions were optimized in a previous study [23]. Rougher flotation tests were performed to demonstrate the effect of residual SIPX removal by activated carbon. Denver flotation machine with $4.5 \mathrm{~L}$ cell was used for flotation tests. Flotation test conditions and chemicals used in the tests are summarized in Table 2.

Table 2. Rougher flotation conditions.

\begin{tabular}{|c|c|}
\hline \multicolumn{2}{|r|}{ Rougher Flotation Conditions } \\
\hline Grinding & $\begin{array}{c}3 \mathrm{~kg} / \mathrm{t} \mathrm{MBS}, 0.5 \mathrm{~kg} / \mathrm{t} \mathrm{Na} \mathrm{S} \text { and } 1 \mathrm{~kg} / \mathrm{t} \mathrm{ZnSO}_{4} ; \mathrm{P}_{80}=45 \mu \mathrm{m} . \text {, (35 min } \\
\text { of grind.) }\end{array}$ \\
\hline Pulp Density & $\% 33 w / w$ \\
\hline Pre-float & Frother: $20 \mathrm{~g} / \mathrm{t}$ MIBC (5 min) \\
\hline Cu Rougher Flotation & Collector: $80 \mathrm{~g} / \mathrm{t} \mathrm{Na}$-AeroFloat, flotation time: $12 \mathrm{~min}$. \\
\hline Zn Rougher Flotation & $\begin{array}{c}\mathrm{pH} 11 \text { (lime), activator: } 350 \mathrm{~g} / \mathrm{t} \mathrm{CuSO}_{4} \text {, collector: } 30 \mathrm{~g} / \mathrm{t} \mathrm{SIPX,} \\
\text { flotation time: } 12 \mathrm{~min} .\end{array}$ \\
\hline
\end{tabular}

Rougher kinetic flotation tests were carried out to demonstrate the effects of water recirculation from tailing discharge with and without treatment. Four cycles were conducted to obtain stable water chemistry in the tests. The recirculated $\mathrm{Zn}$ rougher tail water was adjusted as $70 \%$ flotation tailing and $30 \%$ freshwater considering the water balance in the flotation circuit. Tap water was used as a freshwater source. The chemical composition of tap water is given in Table 3.

Table 3. Chemical composition (mg/L) of tap water used for flotation tests.

\begin{tabular}{cccccc}
\hline Chloride & Nitrate & Sulfate & Thiosulfate & Calcium & Magnesium \\
\hline 15.9 & 8.8 & 20.9 & n.a & 30.5 & 5.1 \\
\hline
\end{tabular}


$\mathrm{Zn}$ rougher tail water of each test was mixed with $250 \mathrm{~g}$ activated carbon for 15 min to adsorb the residual xanthate for treated tests. Treated water was filtered and used as feed water for the second test. The test procedure is illustrated schematically in Figure 1 [23].

Recirculated Water $(70 \%$ Tail Water+ $30 \%$ Fresh Water)

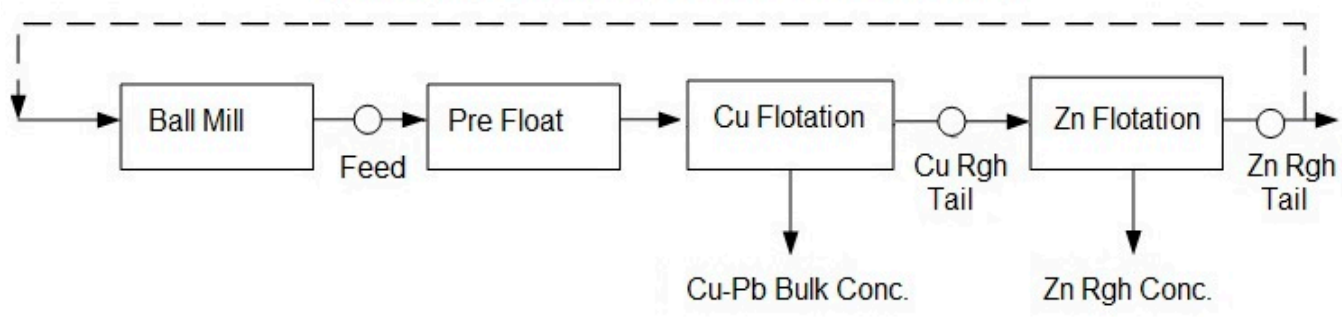

\section{Water Sampling Point}

Figure 1. Flotation test flowsheet and water sampling points.

Water samples were taken for chemical analysis from Feed, $\mathrm{Cu}$ Rougher Tail, and $\mathrm{Zn}$ Rougher Tail, as shown in Figure 1, to follow the changes in water chemistry in rougher flotation stages of the flotation circuit. Calcium and magnesium concentrations were measured by ICP-OES (Iris Intrepid, Thermo Elemental, Franklin, MA, USA). Ion chromatography (ICS-3000, Dionex, Sunnyvale, CA, USA) was used for the detection of anions in solutions. The concentration of xanthate was determined by UV-Vis spectrometer (Multispect 1501, Shimadzu, Kyoto, Japan). Chemical analysis of the flotation products was done by an atomic absorption spectrometer (240FS, Varian, Mulgrave, Australia). TPS-meter (90 FLMV, TPS, Brendale, Australia) was used to measure Eh, pH, and conductivity of the water samples.

\section{Results and Discussions}

\subsection{Adsorption Studies}

\subsubsection{Selection of Activated Carbon Sample}

Activated carbon is a commonly used adsorbent for the removal of organics. The adsorption properties depend mainly on its surface area and microporous structure. They have high internal porosity and hence high adsorptivity. In this study, four granular activated carbon samples (AC-1, AC-2, AC-3, and AC-4) with different surface properties were tested for the removal of xanthate. Two grams carbon sample was mixed with $50 \mathrm{~mL}$, $1590 \mathrm{mg} / \mathrm{L}$ xanthate solution for $15 \mathrm{~min}$. The activated carbon was filtered and the residual xanthate in the solution was measured with UV-Vis. The procedure was repeated for 12 times by reusing the carbon sample to achieve maximum adsorption. As illustrated in Figure 2, AC-4 had the highest adsorption capacity since it has the largest surface area of $1699 \mathrm{~m}^{2} / \mathrm{g}$ (Table 1) among all samples. A total of $214 \mathrm{mg}$ xanthate was removed by AC-4. AC-4 was selected for further studies due to its higher adsorption capacity.

\subsubsection{Regeneration of Activated Carbon}

Activated carbon has a certain adsorption capacity. As more components are adsorbed on its surface, the adsorption capacity decreases over time. Once the maximum adsorption capacity is reached, it can no longer be effectively used. For the regeneration of activated carbon samples, adsorbed components can be destroyed by heating. In this part of the study, the spent activated carbon sample (AC-4) which adsorbed $214 \mathrm{mg}$ of xanthate on its surface (Section 3.1.1) was regenerated by heating at $550{ }^{\circ} \mathrm{C}$ for $1 \mathrm{~h}$. Adsorption performance of the fresh and regenerated carbon samples was compared in Figure 3. The cumulative adsorbed xanthate was $228 \mathrm{mg}$ with the regenerated AC-4 and $214 \mathrm{mg}$ with the fresh AC-4 sample. The results showed that the adsorbed xanthate on spent activated carbon was destroyed, it was restored efficiently and ready for reuse. 


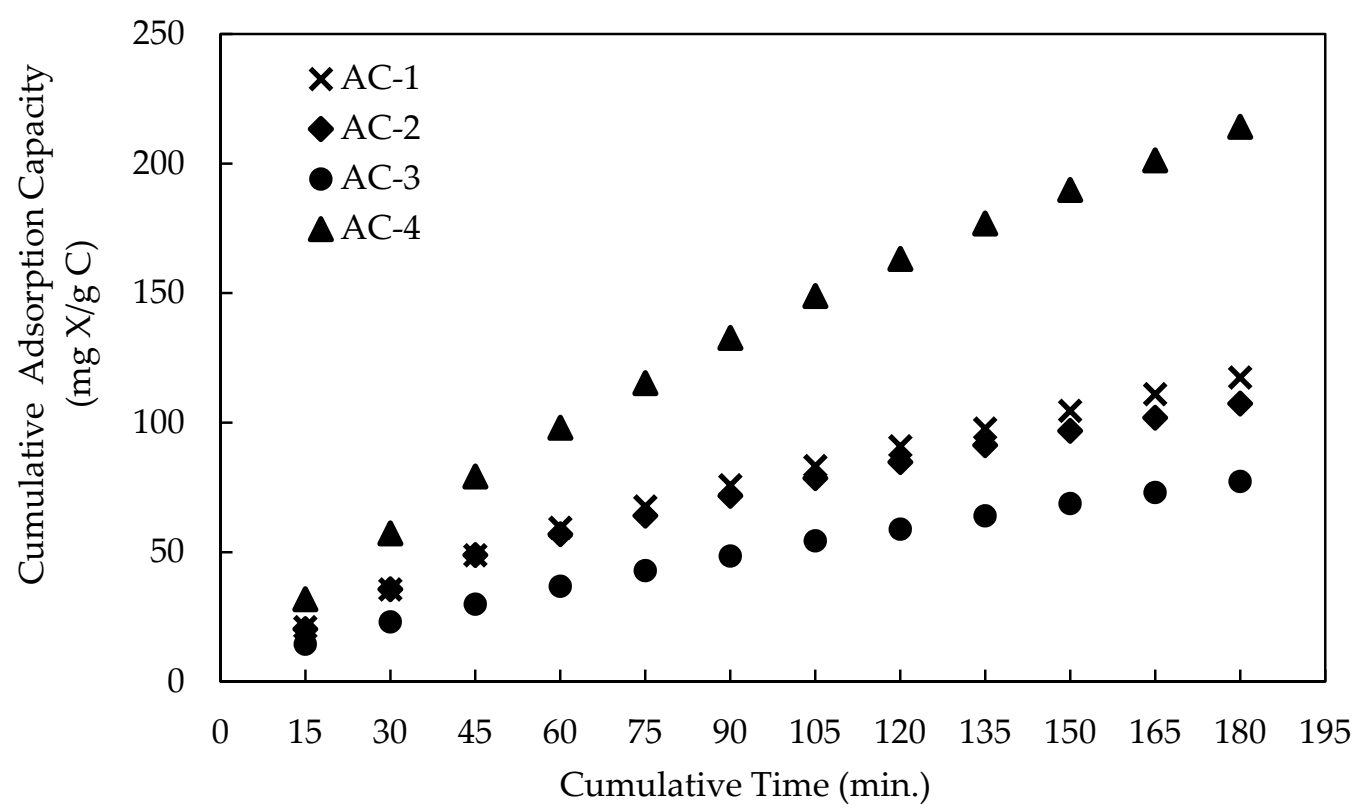

Figure 2. The amount of xanthate adsorbed by the reused activated carbon samples; agitation speed, $200 \mathrm{rpm} ; 50 \mathrm{~mL}$ xanthate solution (1590 mg/L); the amount of activated carbon, $2 \mathrm{~g}$.

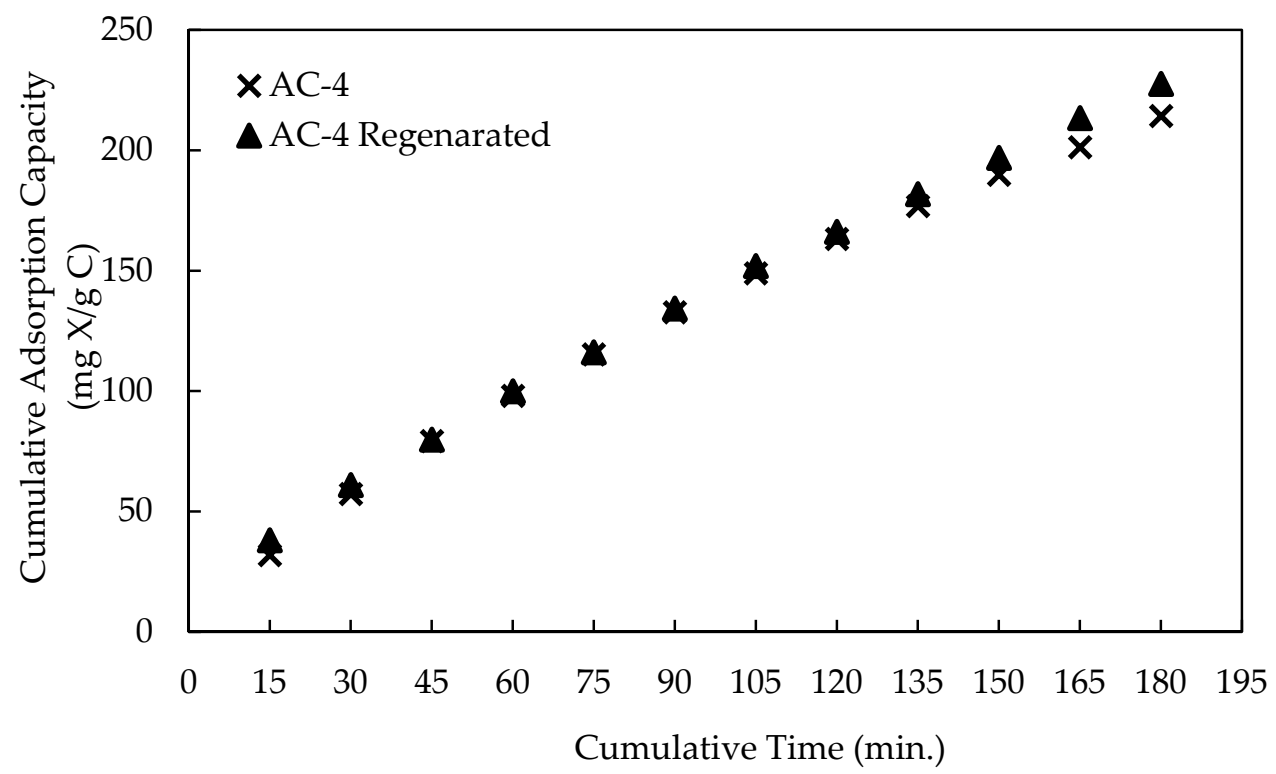

Figure 3. The amount of xanthate adsorbed by fresh and regenerated AC-4; agitation speed, 200 rpm; the volume of xanthate solution, $50 \mathrm{~mL}$; amount of activated carbon, $2 \mathrm{~g}$.

\subsubsection{Effect of Initial Concentration and Contact Time}

Adsorption of xanthate with varying contact times (10-210 $\mathrm{min}$ ) and initial concentrations $(50-800 \mathrm{mg} / \mathrm{L})$ are shown in Figure 4 . The amount of xanthate adsorbed on the activated carbon increased with an increase in agitation time and then reached a maximum value. In the first $60 \mathrm{~min}$, the adsorption was fast as the binding process between xanthate and the adsorption sites of the activated carbon were totally and efficiently completed. After $60 \mathrm{~min}$, the adsorption process was slower due to the saturation of active sites of the carbon [24]. 


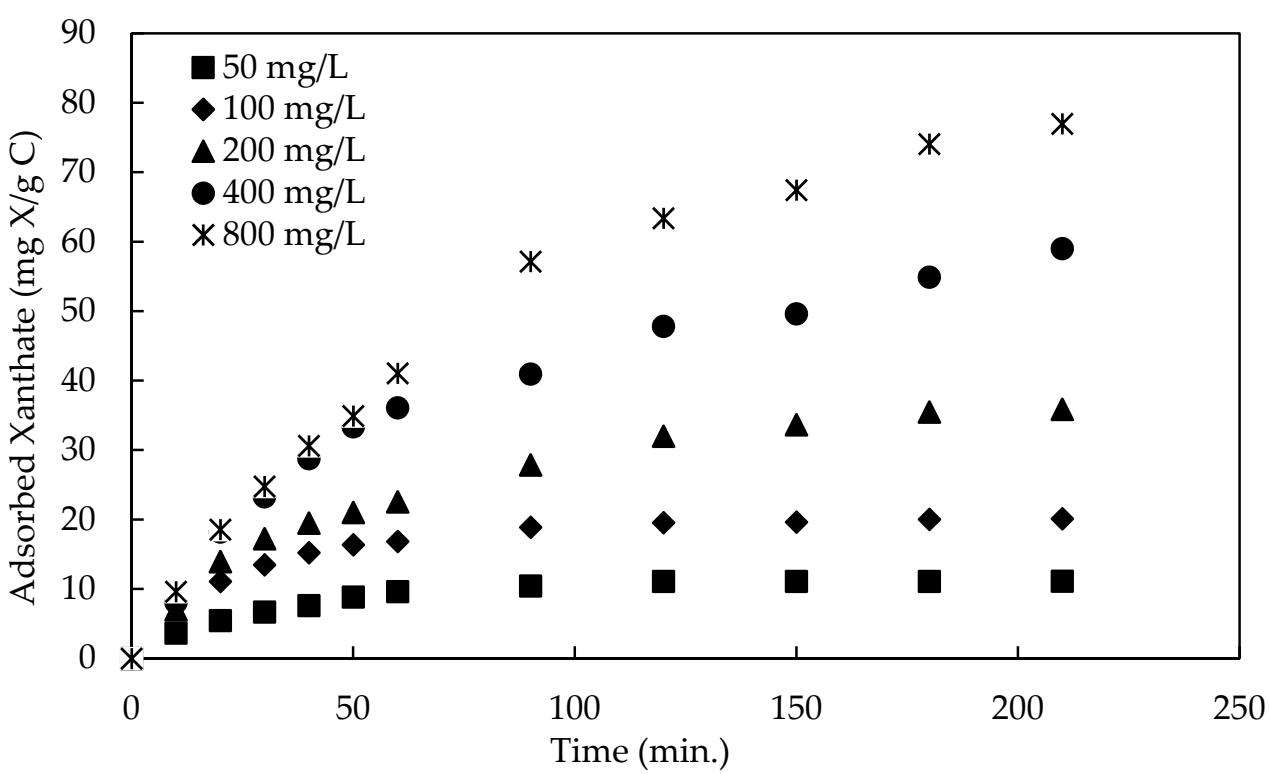

Figure 4. Effect of contact time and initial concentration on the adsorption process of xanthate on activated carbon; agitation speed, $200 \mathrm{rpm}$; the volume of xanthate solution, $100 \mathrm{~mL}$; the amount of activated carbon, $0.5 \mathrm{~g}$.

At equilibrium, the amount of adsorbed xanthate increased from $11 \mathrm{mg} / \mathrm{g}$ at $50 \mathrm{mg} / \mathrm{L}$ initial concentration to $77 \mathrm{mg} / \mathrm{g}$ at $800 \mathrm{mg} / \mathrm{L}$ in $210 \mathrm{~min}$ adsorption time. This indicates that the collision rate between the xanthate molecules and the activated carbon particles is enhanced at high xanthate concentrations. As a result, more xanthate was transferred to the surface of the carbon. On the other hand, more time was required to reach the equilibrium at high xanthate concentrations because xanthate dispersed deeply on the inner surface of the carbon and occupied more adsorption sites [25]. Figure 4 shows that the contact time required to reach equilibrium decreased at lower xanthate concentrations.

\subsubsection{Adsorption Isotherm}

Langmuir adsorption model was applied for fitting of the experimental data. Langmuir model is based on the assumption of a homogeneous adsorbent surface with identical adsorption sites which means that the adsorption takes place equally on the active sites of the adsorbent and once an adsorbate occupies a place, no further adsorption can take place at that site [26]. Langmuir model is given by the following equation:

$$
\frac{C_{e}}{Q_{e}}=\frac{1}{Q_{m}} C_{e}+\frac{1}{K_{L} Q_{m}}
$$

where $C_{e}$ is the xanthate concentration at equilibrium in solution $(\mathrm{mg} / \mathrm{L}) ; Q_{e}$ the equilibrium xanthate concentration on the activated carbon $(\mathrm{mg} / \mathrm{g}) ; K_{L}$ Langmuir adsorption constant $(\mathrm{L} / \mathrm{mg})$, and $Q_{m}$ is the maximum adsorption capacity $(\mathrm{mg} / \mathrm{g})$ of activated carbon. A plot of $C_{e} / Q_{e}$ versus $C_{e}$ for the adsorption of xanthate onto activated carbon should show a linear relationship if the adsorption of xanthate on the activated carbon is followed by the Langmuir isotherm model. The slope, $1 / Q_{m}$ and intercept, $1 / K_{L} . Q_{m}$ of this line gives the values of $Q_{m}$ and $K_{L}$, and theoretical $Q_{m}$ calculated by slope should be close to the experimental adsorption amount [27]. The Langmuir plots (Figure 5) have good linearity, $R=0.9918$ and the Langmuir model constant can be given as follows; monolayer adsorption capacity, $Q_{m}, 86.2 \mathrm{mg} / \mathrm{g}$ and Langmuir adsorption constant, $K_{L}, 0.0704 \mathrm{~L} / \mathrm{mg}$. 


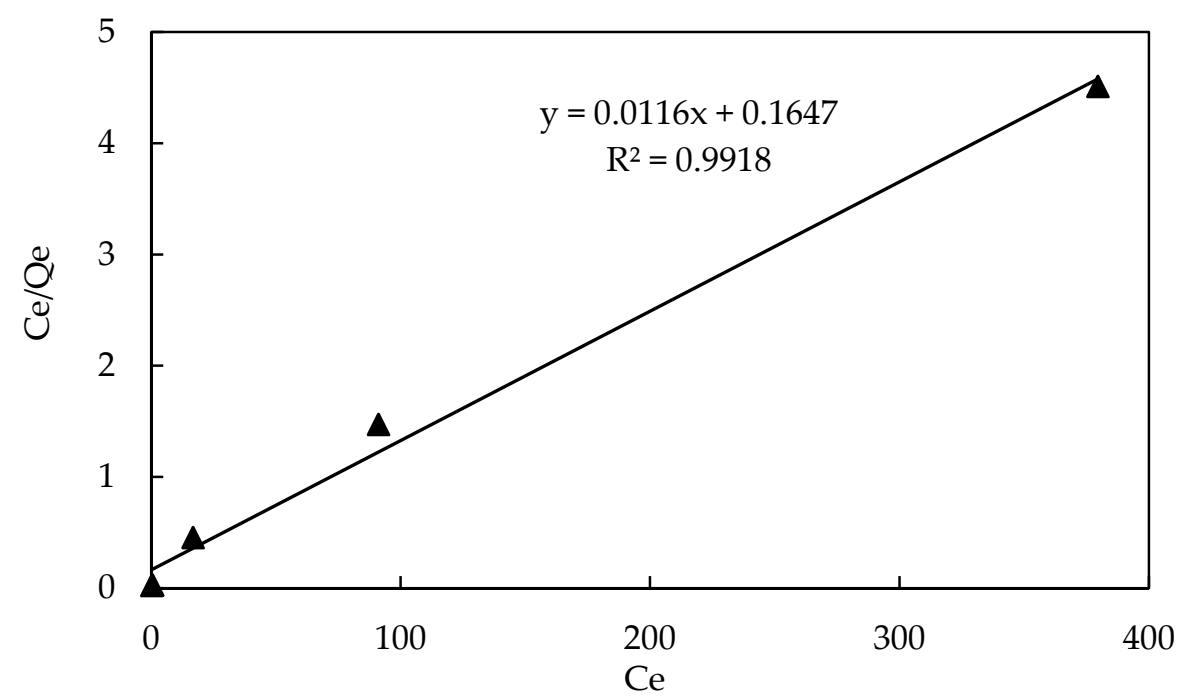

Figure 5. Langmuir adsorption isotherm for xanthate on activated carbon with various initial xanthate concentrations $C_{0}(50,100,200,400$ and $800 \mathrm{mg} / \mathrm{L})$; volume of xanthate solution, $100 \mathrm{~mL}$; amount of activated carbon, $0.5 \mathrm{~g}$; contact time, $180 \mathrm{~min} . C_{e}$ is the xanthate concentration at equilibrium.

\subsection{Flotation Studies}

\subsubsection{Water Chemistry}

The chemical composition of water samples taken from the flotation feed (i.e., after grinding), $\mathrm{Cu}$ rougher ( $\mathrm{Rgh}$ ), and $\mathrm{Zn}$ rougher ( $\mathrm{ggh}$ ) flotation tails were analyzed to determine the effect of water quality on flotation performance. The flotation results obtained from treated and non-treated process water samples were compared to demonstrate the impact of water treatment on the flotation efficiency. Sulfate, thiosulfate, calcium, and xanthate ions were found as the major components in the process water. They are generated in the flotation process water mostly by the oxidation/dissolution of the ore and the addition of flotation chemicals [28]. Recirculation of process water causes a significant increase in ion concentration due to the building up of the ions [29].

Variations in the sulfate concentration during flotation tests are given in Figure 6. The sulfate concentration in the tap water was $20 \mathrm{mg} / \mathrm{L}$ (Table 3) and increased to $1624.8 \mathrm{mg} / \mathrm{L}$ in the feed water of the first cycle (Figure 6a) due to the oxidation/dissolution of the sulfide minerals during the grinding stage. In the following copper and zinc rougher flotation stages the sulfate concentration decreased to $1400 \mathrm{mg} / \mathrm{L}$ and $1257 \mathrm{mg} / \mathrm{L}$, respectively. The sulfate concentration was lower in the zinc flotation stage despite addition of $\mathrm{CuSO}_{4}$ for sphalerite activation. This could be attributed to the precipitation of sulfate at high $\mathrm{pH}$ values with the addition of lime in the zinc flotation stage [30]. Sulfate concentration increased considerably in cycle 2 with water circulation. Stable water chemistry conditions were observed in cycle 3 and cycle 4 . A similar trend was observed with the tests performed with water treatment. There were small differences in sulfate concentrations between the tests conducted using non-treated (Figure 6a) and treated (Figure 6b) water.

Thiosulfate ions are produced during grinding and flotation of sulfide minerals due to the oxidation of the sulfide group at about $\mathrm{pH} 9$ [31]. Approximately $39.7 \mathrm{mg} / \mathrm{L}$ thiosulfate entered the flotation feed water during the grinding stage and increased to $144.6 \mathrm{mg} / \mathrm{L}$ at the end of Cycle 4 (Figure 7a). The amount of thiosulfate at the end of Zn rougher flotation stage was slightly higher than the other stages (Figure 7a). However, there was no clear trend between the flotation stages in the tests with water treatment (Figure 7b). The thiosulfate ions are generally oxidized to sulfate during flotation depending on the flotation chemistry and time. The small differences between each cycle might resulted in the fluctuated thiosulfate concentrations. 

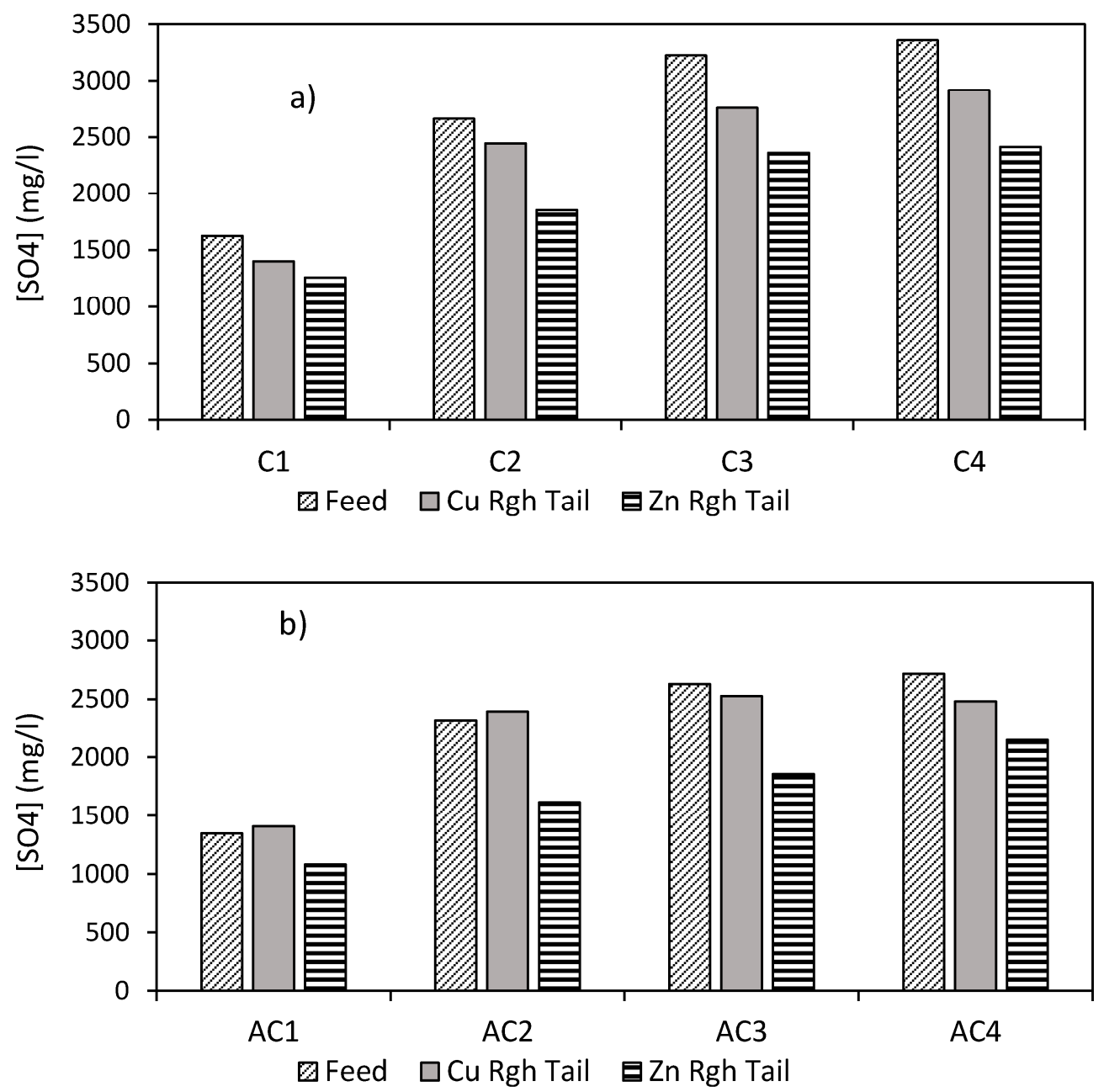

Figure 6. Dissolved ion concentration of sulfate ions at different stages of flotation tests during water recirculation without (a) and with (b) treatment.

Calcium ions enter the process water mainly through dissolution of calcium minerals, lime addition and raw water resources [32]. The tap water used for flotation contained $30.7 \mathrm{mg} / \mathrm{L}$ calcium and that increased to $204.6 \mathrm{mg} / \mathrm{L}$ calcium after the grinding stage in cycle 1 as illustrated in Figure 8. This was attributed to dissolution of the calcium containing minerals in the ore because there was no lime addition at the grinding stage. The concentration of calcium ions of Cycle 1 in $\mathrm{Zn}$ rougher tail increased to $347 \mathrm{mg} / \mathrm{L}$ due to lime addition to adjust the $\mathrm{pH}$ at 11 . The slight increase could be attributed to the partial precipitation of the calcium and sulfate ions in the form of gypsum during flotation. The calcium content of the feed water of Cycle 4 reached $474.5 \mathrm{mg} / \mathrm{L}$ due to the accumulation of calcium ions in the recirculated process water.

The results given in Figure 9 showed that the xanthate ion concentration increased considerably as the $\mathrm{Zn}$ rougher tail water was recirculated. In cycle 1 , the concentration of residual xanthate was $0.39 \mathrm{mg} / \mathrm{L}$ and increased up to $0.96 \mathrm{mg} / \mathrm{L}$ in the final cycle by water recirculation. This concentration was enough to cause flotation of the copper minerals in the pre-float stage. In the second set of flotation tests, the $\mathrm{Zn}$ rougher tail water of each cycle was treated with activated carbon to remove residual xanthate and recirculated back into the grinding and $\mathrm{Cu}$ Rougher flotation stages as feed water. UV-Vis spectrophotometry analysis of the treated water samples showed that the absorption band at $301 \mathrm{~nm}$ disappeared after treatment. Therefore, the zero concentration readings could not be illustrated in the graph. 

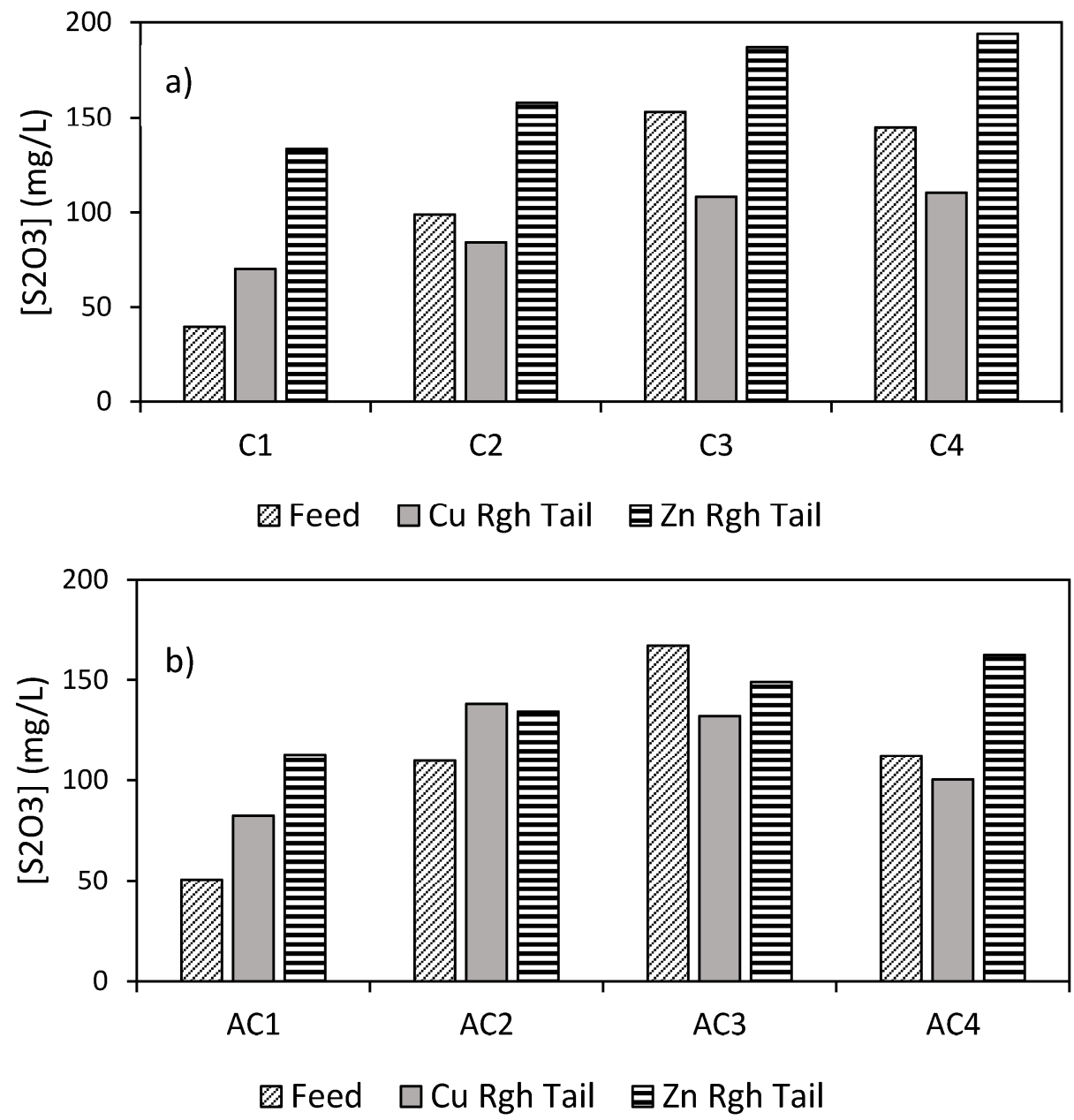

Figure 7. Dissolved ion concentration of thiosulfate ions at different stages of flotation tests during water recirculation without (a) and with (b) treatment.

The results showed that $\mathrm{AC}$ was an effective material for the removal of xanthate in aqueous solutions. Similar results were reported in various studies using AC [33] and bentonite as adsorbents [17]. Modified bentonite has been used successfully to remove $92.7 \%$ xanthate from the flotation plant water of a copper mine [18]. However, AC has commonly been accepted for industrial applications due to its lower cost and easy supply.

The following conclusions were deduced from the water chemistry measurements shown in this section. Water treatment using AC did not significantly affect the concentrations of sulfate, thiosulfate, and calcium ions in the process water. On the other hand, the residual xanthate was completely removed by activated carbon. It can be said that the activated carbon adsorption method is effective for the removal of residual organic ions but not the rather than inorganic ions.

\subsubsection{Pre-Flotation Section}

Figure 10 shows $\mathrm{Cu}$ and $\mathrm{Zn}$ grades and recoveries in pre-flotation concentrate for the tests with and without water treatment using activated carbon (AC). The copper grade and recovery were significantly higher with the test performed without water treatment. While the copper recovery increased from about $2 \%$ in cycle 1 up to $25 \%$ in cycle 4 , the copper grade increased from $0.77 \%$ to $7.49 \%$. A similar trend can be seen for the zinc recovered to the pre-float product, at a much lower rate. This was attributed to the presence of residual xanthate ions in the circulated water. Residual xanthates and their oxidation products in process water could absorb on sulfide minerals and reduce selectivity in the pre-flotation section where the naturally floatable gangue minerals are removed from the pulp [32]. 
After water treatment, the copper grade and recovery decreased to about $0.8 \%$ and $2 \%$ respectively in all cycles.
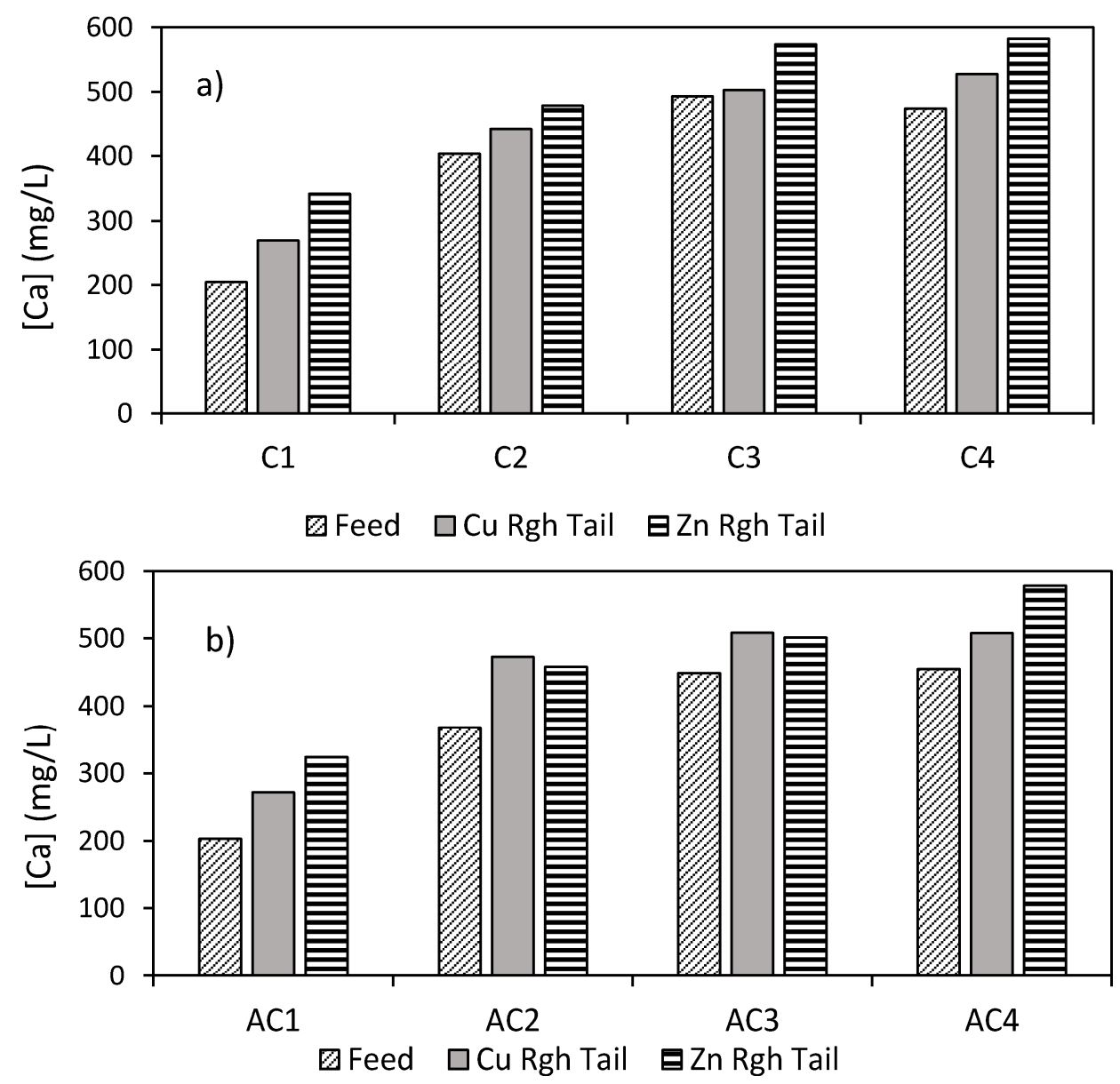

Figure 8. Dissolved ion concentration of calcium ions at different stages of flotation tests during water recirculation without (a) and with (b) treatment.

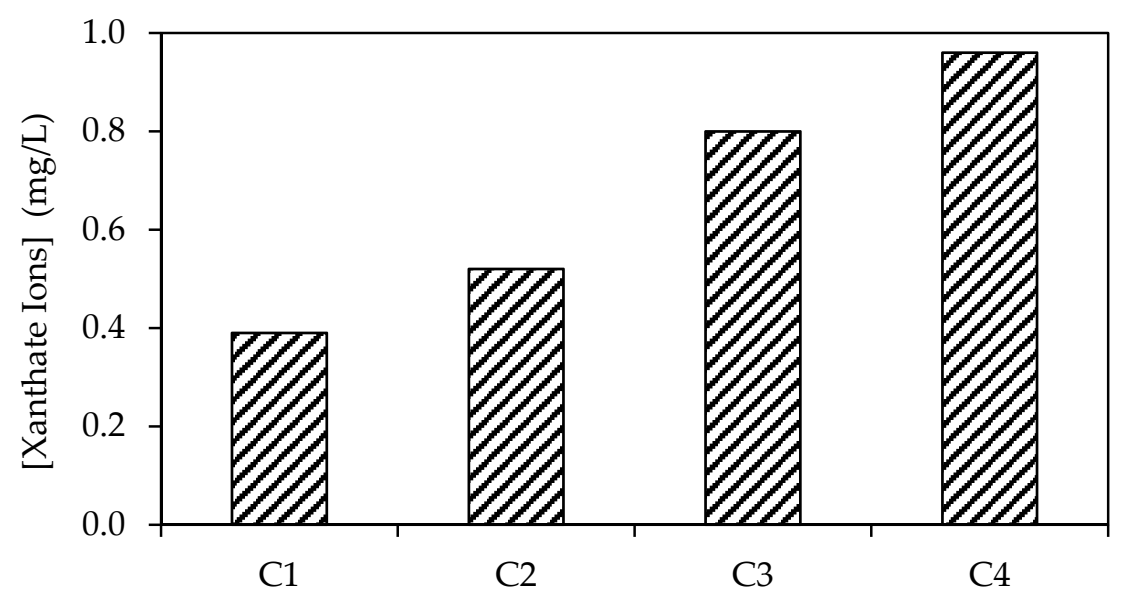

Figure 9. Xanthate ion concentration in Zn Rougher Tail water during water recirculation without AC treatment.

\subsection{3. $\mathrm{Cu}$ Rougher Flotation Section}

The impact of water treatment on $\mathrm{Cu}$ rougher flotation efficiency is presented in Figure 11. Loss of copper to the pre-flotation concentrate resulted in a significant drop in the copper recovery at the rougher flotation stage. While the copper recovery decreased 
from $75.3 \%$ down to $47 \%$ with the recirculation of non-treated process water, the copper grade decreased from $7.22 \%$ in cycle 1 to $2.49 \%$ in cycle 4 . After water treatment, the copper grade and recovery were restored and increased to over $8 \%$ and $70 \%$ respectively and remained almost identical in all cycles. Flotation of sphalerite was not significantly affected because of the depressant additions to minimize its recovery to the copper rougher concentrate.
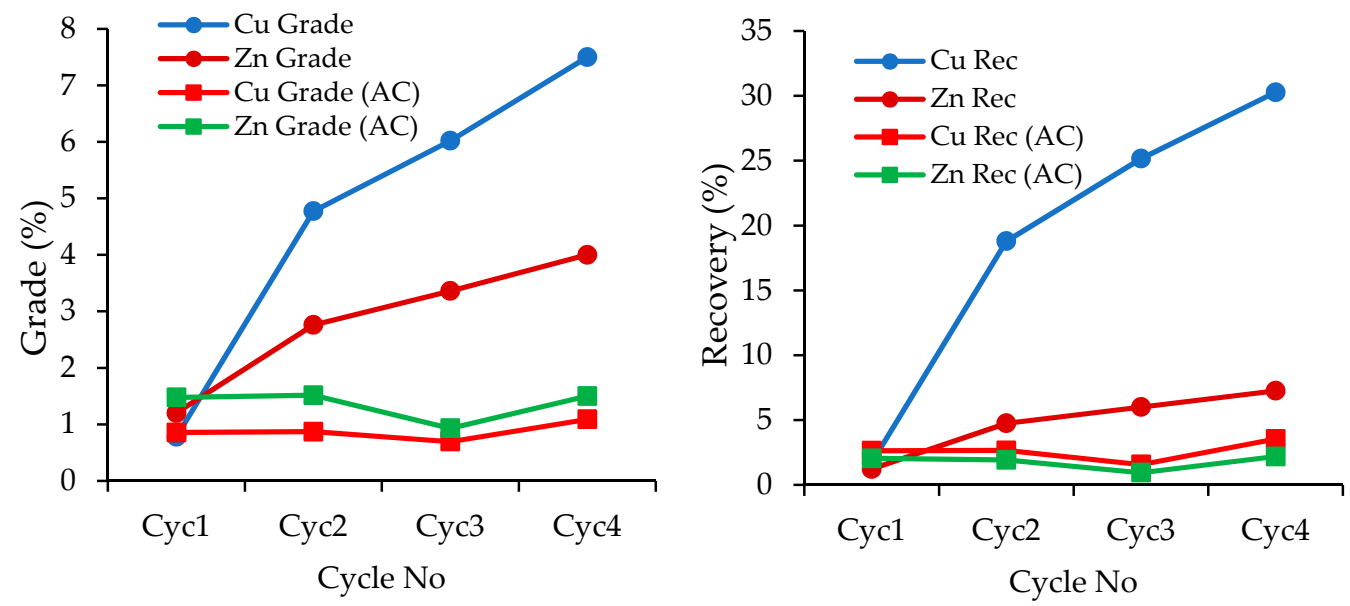

Figure 10. $\mathrm{Cu}$ and $\mathrm{Zn}$ grades and recoveries to pre-flotation concentrate with and without the use of activated carbon (AC) for water treatment.
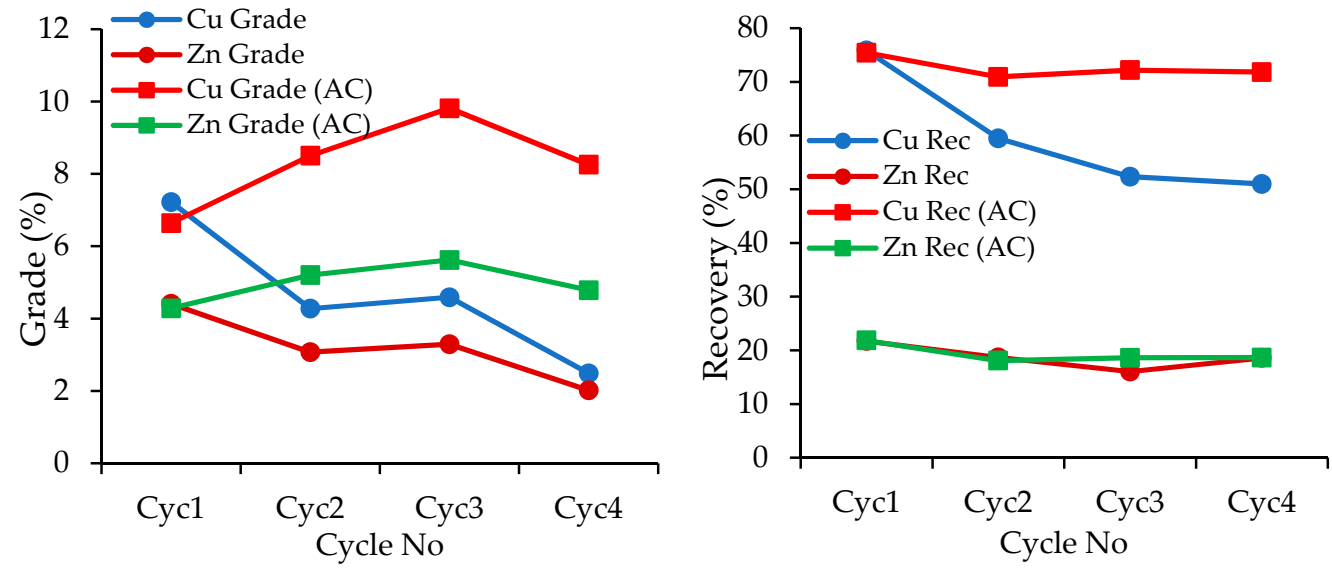

Figure 11. $\mathrm{Cu}$ and $\mathrm{Zn}$ grades and recoveries to $\mathrm{Cu}$ Rougher Concentrate with $(\mathrm{AC})$ and without use of activated carbon for water treatment.

\section{Conclusions}

In this research, the effects of water recirculation with and without treatment on the flotation performance of a $\mathrm{Cu}-\mathrm{Zn}$ sulfide ore were investigated. Based on the findings following conclusions were deduced:

- Naturally floatable gangue minerals (mainly talc) were removed by applying the pre-flotation stage before the copper rougher flotation stage.

- Water recirculation without treatment caused significant copper loss to the pre-flotation concentrate.

- Granular activated carbon (AC-4) was used to remove the residual xanthate in $\mathrm{Zn}$ rougher tail water. The adsorption data were found to follow the Langmuir adsorption isotherm model with the maximum monolayer adsorption capacity of $86.2 \mathrm{mg} / \mathrm{g}$.

- The activated carbon could easily be regenerated by heating at $550{ }^{\circ} \mathrm{C}$.

- $\quad$ Ore dissolution during grinding and flotation was found to be the most important mechanism affecting process water chemistry. 
- Water treatment by AC did not significantly influence the concentration of sulfate, thiosulfate, and calcium ions.

- Flotation tests with the recirculation of treated water showed that loss of copper and zinc to the pre-float section was prevented and the flotation efficiency was restored after treatment.

Author Contributions: Y.O.: Conceptualization, Methodology, Investigation, Writing—original draft, Writing—review \& editing. O.B.: Conceptualization, Methodology, Writing—review \& editing Z.E.: Supervision, Conceptualization, Methodology, Funding acquisition, Writing-review \& editing. All authors have read and agreed to the published version of the manuscript.

Funding: This research received no external funding.

Acknowledgments: The authors would like to thank Polimetal Madencilik A.Ş for their technical and financial support.

Conflicts of Interest: The authors declare no conflict of interest.

\section{References}

1. Levay, G.; Schumann, R. A System Approach to Water Quality Management in the Minerals Processing Industry, Water in Mining; The Australian Institute of Mining and Metallurgy: Brisbane, Australia, 2006; pp. 277-287.

2. Luukkanen, S.; Parvinen, P.; Miettinen, M.; Stén, P.; Lähteenmäki, S.; Tuikka, A. Monitoring the composition of water of flotation slurries with an on-line analyser. Miner. Eng. 2003, 16, 1075-1079. [CrossRef]

3. Stén, P.; Parvinen, P.; Miettinen, M.; Luukkanen, S.; Kaskiniemi, V.; Aaltonen, J. On-line analysis of flotation process waters at Siilinjärvi (Finland) apatite concentrating plant. Min. Eng. 2003, 16, 229-236. [CrossRef]

4. Broman, P.G. Water reuse at sulfide ore concentrators in Sweden: Practice, experience and current development. In Complex Sulphide Ores; Jones, M.J., Ed.; The Institution of Mining and Metallurgy: London, UK, 1980; pp. 28-39.

5. Hoover, M.R. Water chemistry effects in the flotation of sulphide ores-A review and discussion for molybdenite. In Complex Sulphide Ores; Jones, M.J., Ed.; Institution of Mining and Metallurgy: London, UK, 1980; pp. 100-112.

6. Levay, G.; Smart, R.S.C.; Skinner, W.M. The impact of water quality on flotation performance. J. S. Afr. Inst. Min. Metall. 2001, 101, 69-75.

7. Malysiak, V.; Shackleton, N.J.; de Vaux, D. Effect of water quality on pentlandite-pyroxene floatability with emphasis on calcium ions. In Proceedings of the 22nd International Mineral Processing Congress, Cape Town, South Africa, 28 September-3 October 2003.

8. Rao, S.R.; Finch, J.A. A review of water reuse in flotation. Min. Eng. 1989, 2, 65-85. [CrossRef]

9. Slatter, K.A.; Plint, N.D.; Cole, M.; Dilsook, V.; De Vaux, D.; Palm, N.; Oostendorp, B. Water management in Anglo Platinum process operations: Effects of water quality on process operations. In Proceedngs of the Abstracts of International Mine Water Conference, Pretoria, South Africa, 19-23 October 2009; pp. 46-55.

10. Lam, K.S. Biodegradation of Xanthate by Microbes Isolated from a Tailings Lagoon and a Potential Role for Biofilm and Plant/Microbe Associations. Ph.D. Thesis, Western Sydney University, Penrith, Australia, 1999.

11. Muzinda, I.; Schreithofer, N. Water quality effects on flotation: Impacts and control of residual xanthates. Min. Eng. 2018, 125, 34-41. [CrossRef]

12. Shen, Y.; Nagaraj, D.R.; Farinato, R.; Somasundaran, P. Study of xanthate decomposition in aqueous solutions. Min. Eng. 2016, 93, 10-15. [CrossRef]

13. Liu, R.; Sun, W.; Ouyang, K.; Zhang, L.; Hu, Y. Decomposition of sodium butyl xanthate (SBX) in aqueous solution by means of OCF: Ozonator combined with flotator. Min. Eng. 2015, 70, 222-227. [CrossRef]

14. Fu, P.; Wang, L.; Ma, Y.; Hou, Z. A comparative study on the degradation of ethyl xanthate collector by $\mathrm{O}_{3}, \mathrm{UV}_{254 \mathrm{~nm}}, \mathrm{UV}_{185+254 \mathrm{~nm}}$,

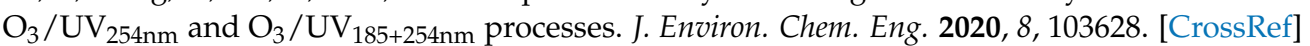

15. García-Leiva, B.; Teixeira, L.A.C.; Torem, M.L. Degradation of xanthate in waters by hydrogen peroxide, fenton and simulated solar photo-fenton processes. J. Mater. Res. Technol. 2019, 8, 5698-5706. [CrossRef]

16. Chen, S.; Gong, W.; Mei, G.; Zhou, Q.; Bai, C.; Xu, N. Primary biodegradation of sulfide mineral flotation collectors. Min. Eng. 2011, 24, 953-955. [CrossRef]

17. Amrollahi, A.; Massinaei, M.; Moghaddam, A.Z. Removal of the residual xanthate from flotation plant tailings using bentonite modified by magnetic nano-particles. Min. Eng. 2019, 134, 142-155. [CrossRef]

18. Rezaei, R.; Massinaei, M.; Moghaddam, A.Z. Removal of the residual xanthate from flotation plant tailings using modified bentonite. Min. Eng. 2018, 119, 1-10. [CrossRef]

19. Huang, Q.; Li, X.; Rena, S.; Luo, W. Removal of ethyl, isobutyl, and isoamyl xanthates using cationic gemini surfactant-modified montmorillonites. Colloids Surf. A 2019, 580, 123723. [CrossRef]

20. Dong, Y.B.; Lin, H.; Liu, Q.L.; Huo, H.X. Treatment of flotation wastewater using biological activated carbon. J. Cent. South Univ. 2014, 21, 3580-3587. [CrossRef] 
21. Morris, G.E.; Fornasiero, D.; Ralston, J. Polymer depressants at the talc-water interface adsorption isotherm, microflotation and electrokinetic studies. Int. J. Miner. Process. 2002, 67, 211-227. [CrossRef]

22. Wang, J.; Somasundaran, P.; Nagaraj, D.R. Adsorption mechanism of guar gum at solid-liquid interfaces. Min. Eng. 2005, 18, 77-81. [CrossRef]

23. Ozturk, Y. Development of Wastewater Treatment Methods for Flotation Plants. Ph.D. Thesis, Graduate School of Science and Engineering, Hacettepe University, Ankara, Turkey, 2008.

24. Kuang, Y.; Zhang, X.; Zhou, S. Adsorption of Methylene Blue in Water onto Activated Carbon by Surfactant Modification. Water 2020, 12, 587. [CrossRef]

25. Chiang, C.H.; Chen, J.; Lin, J.H. Preparation of pore-size tunable activated carbon derived from waste coffee grounds for high adsorption capacities of organic dyes. J. Environ. Chem. Eng. 2020, 8, 103929. [CrossRef]

26. Oguz, E. Adsorption characteristics and the kinetics of the $\mathrm{Cr}(\mathrm{VI})$ on the Thuja oriantalis. Colloid Surf. 2005, 252, 121-128. [CrossRef]

27. Demiral, H.; Demiral, I.; Tumsek, F.; Karabacakoğlu, B. Adsorption of chromium (VI) from aqueous solution by activated carbon derived from olive bagasse and applicability of different adsorption models. Chem. Eng. J. 2008, 144, 188-196. [CrossRef]

28. Rao, S.R. Resource recovery and recycling from metallurgical wastes. In Waste Management; Waste Management Series 7; Elsevier Science Ltd.: Amsterdam, The Netherlands, 2006; pp. 473-475. ISBN -13 9780080463209.

29. Öztürk, Y.; Ekmekçi, Z. Removal of sulfate ions from process water by ion exchange resins. Min. Eng. 2020, 159, 106613. [CrossRef]

30. Ikumapayi, F.; Makitalo, M.; Johansson, B.; Rao, K.H. Recycling of process water in sulphide flotation: Effect of calcium and sulphate ions on flotation of galena. Min. Eng. 2012, 39, 77-88. [CrossRef]

31. Kuyucak, N.; Yaschyshyn, D. Managing Thiosalts in mill effluents, studies conducted at the kidd metallurgical. In Proceedings of the Mining and the Environment IV Conference, Sudbury, ON, Canada, 19-27 October 2007.

32. Liu, W.; Moran, C.J.; Vink, S. A review of the effect of water quality on flotation. Min. Eng. 2013, 53, 91-100. [CrossRef]

33. Salarirad, M.M.; Behnamfard, A.; Veglio, F. Removal of xanthate from aqueous solutions by adsorption onto untreated and acid/base treated activated carbons. Desalin. Water Treat. 2021, 212, 220-233. [CrossRef] 